\title{
Construction of "Modular" Off-Campus Training Project System for Logistics Management Major in Higher Vocational Colleges Based on Modern Apprenticeship System*
}

\author{
Shijun Yuan \\ Hunan Modern Logistics College \\ Changsha, China 410131
}

\author{
Xiangyang Liao ${ }^{* *}$ \\ Hunan Modern Logistics College \\ Changsha, China 410131 \\ **Corresponding Author
}

\begin{abstract}
In current talent training mode of modern apprenticeship system, the off-campus training base jointly built by colleges and enterprises plays a key role in the training of advanced technical and skilled talents in higher vocational colleges. This paper analyzes problems of the former off-campus training base including single construction mode, incomplete training project and imperfect teaching function, and constructs a modular off-campus training project system comprising three levels of basic skills, professional skills, technical application or comprehensive skills training.
\end{abstract}

Keywords-logistics management major; module; training project; system

\section{INTRODUCTION}

The cultivation of advanced technical and skilled talents of logistics management major in higher vocational colleges is inseparable from practical teaching. Plan for the Construction of Modern Vocational Education System (2014-2020) also requires that "teaching space and curriculum modules should be designed according to the real business process of production services". At present, the off-campus training base for logistics management major of higher vocational colleges provides obvious advantages for students to acquire practical knowledge and train practical operation skills of logistics profession. To further tap off-campus training base's potential of logistics personnel training in higher vocational colleges, this paper analyzes the current situation of off-campus training base for logistics management major of higher vocational colleges, and presents the "modular" off-campus training system structure.

\section{ANALYSIS ON THE CURRENT SituATION OF TRAINING BASE FOR LOGISTICS MANAGEMENT MAJOR OF HIGHER VOCATIONAL COLLEGES}

In order to meet the practical teaching needs of students

*Fund: The project in "the 13th Five-year Plan for Education Science in Hunan Province in 2018 - Phased Results based on Research on "Doublesubject and Dual-identity" Apprentice Collaborative Management Mechanism (XJK18BZY042) in School-enterprise Cooperative Secondary College. majoring in logistics management in higher vocational colleges, such as professional course training, in-post practice training and graduation comprehensive training, higher vocational colleges generally establish college-enterprise cooperative relationship with industrial enterprises to jointly construct a off-campus practice and training base. The offcampus training base exerts a vital role in cultivating students' practical ability and also meets the labor needs of employers. To some extent, it has achieved the win-win cooperation between colleges and enterprises, and accelerated the development of logistics teaching and industry. But meanwhile, there are also the following problems in the development of the off-campus training base:

\section{A. Single Mode of Off-campus Training Base}

Now, some higher vocational colleges, which do not cooperate closely with logistics industry enterprises, are faced with the situation of "welcomed college and unwelcomed enterprise" in the construction of off-campus training bases. Therefore, colleges often do not have much initiative in building off-campus training bases. As long as enterprises are willing to cooperate with them, they will build the base. They do not take too much account of advantages of an enterprise, that is, what kind of training base the enterprise is suitable for and what training projects are suitable for the training base built by the enterprise. The cooperation agreement signed by colleges and enterprises that is listed in enterprises will be mainly supervised by the enterprise professors. This mode fails to fully tap the potential of off-campus training bases, eventually resulting in a repeated construction and low-level construction of off-campus training bases. Therefore, the goal of off-campus training of logistics management major of higher vocational education can't be truly realized.

\section{B. Incomplete Training Projects in Off-campus Training Bases}

A major reason why some enterprises are willing to build training bases with vocational colleges is that they hope to solve the current employment problems of enterprises through the construction of training bases. Enterprises often design 
logistics training projects and build training bases as required by their own work posts, instead of designing systematic training programs from the perspective of the whole major. Therefore, training posts and projects provided by such offcampus training bases are not comprehensive.

\section{Imperfect Teaching Functions of Off-campus Training Base}

From the perspective of practical teaching, requirements of training functions of basic skills, professional skills, technical application or comprehensive skills should be met. Now, some off-campus training bases mainly provide basic skills training, supplemented by professional skills training, while the training of technical application skills or comprehensive skills is basically not carried out.

\section{BASIC IDEAS AND OVERALL STRUCTURE OF THE}

CONSTRUCTION OF "MODULAR" OFF-CAMPUS TRAINING SYSTEM FOR LOGISTICS MANAGEMENT MAJOR OF HIGHER VoCATIONAL COLLEGES BASED ON MODERN APPRENTICESHIP

\section{SYSTEM}

"MES" and "CBE" are two representative schools of modular education model. China's research and practice of modular teaching is earlier than that of "projectized" teaching, which has been explored since the 1990s. MES (Modules of Employable Skills) is a teaching mode developed by International Labour Organization in the early 1970s, focusing on field teaching and skills training. It determines modules based on job tasks, and takes the completion process of the actual post work in a certain profession as the main line, which can be called "task modules".

Represented by Canada, the United States, etc, CBE (Competency Based Education) determines modules based on the executive ability, and takes the cognitive ability and capacity for action that should be possessed in a certain occupation as the main line, which can be called "competency modules".

The commonality of the two schools is that they both emphasize practicability and competence. The difference is that CBE starts from the universal law and demand of occupation and focuses on the basic general ability of the occupation, while MES proceeds from the job specification of specific post and places emphasis on the working ability of vocational posts.

China's vocational education sector has summed up an education mode of "broad foundation and flexible module" that is relatively suitable for our national conditions. The socalled "broad foundation and flexible module" education mode is based on the educational concept of putting people first and fully educating people. In accordance with the training requirements of formal full-time vocational education, through flexible and reasonable collocation between module courses, it first cultivates students' broad basic humanistic quality and basic professional ability, and then develops their qualified professional ability.

With the rapid development of China's logistics service industry, market demand for logistics talents is steadily on the increase. This requires colleges constantly update their concepts, improve their teaching methods and perfect practical teaching venues in the cultivation of logistics related talents. The nature of logistics jobs varies with the demand for logistics talents. Logistics personnel need to master professional knowledge, such as foreign languages, customs, international trade, etc. The demand for logistics talents changes from region to region, industry to industry, and management layer to management layer. Therefore, in order to meet the needs of different posts for different levels of logistics personnel, colleges need to build a "modular" training system for the training of logistics talents.

Educational philosophy, personnel training mode, course construction, and management mode of higher vocational colleges are integrated into the industrial chain to provide an important platform and carrier for the connotative development of the relationship between industry and education. Higher vocational colleges aim to train technical talents of logistics management major, deeply tap the "driving force" for enterprises to participate in the construction of training base, are targeted to look for cooperative enterprises to build off-campus training bases, and lay emphasis on job requirements of supply chain logistics industry and enterprises. Besides, colleges and enterprises jointly construct a modular practical teaching content system including three levels of basic skills, professional skills, technical applications or comprehensive skills training in accordance with basic practice, professional practice and social practice.

The "modular training project" system of off-campus training base for higher vocational logistics management majors is composed of seven first level modules and eighteen second level training submodules. Each submodule includes basic skills training project, professional skills training project, technical application or comprehensive skills training project.

The first level module of warehousing service includes general warehousing service submodule and special goods warehousing service submodule, among which special goods mainly refer to fresh goods, bulky goods, dangerous goods, etc.

The first level module of transport service comprises road transport service submodule, railway transport service submodule, air transport service submodule, waterway transport submodule and multimodal transport service submodule.

The first level module of distribution service consists of commercial chain distribution submodule, industrial manufacturing distribution submodule and third-party logistics distribution submodule.

The first level module of circulation processing service comprises means of production circulation processing submodule and means of livelihood circulation processing submodule.

The first level module of handling service includes vertical handling submodule and horizontal handling submodule.

The first level module of packaging service comprises general cargo packaging submodule and special cargo packaging submodule. 


\section{Strengthening the Teaching Management and Evaluation}

System of "Modular' Training Based on Modern

Apprenticeship System

In order to ensure the coordinated development of

IV. DEVElOPMENT MEASURES OF "MODULAR" OFFCAMPUS TRAINING PROJECT FOR LOGISTICS MANAGEMENT MAJOR OF HIGHER VOCATIONAL COLLEGES BASED ON MODERN APPRENTICESHIP SYSTEM

\section{A. Colleges Take the Initiative to Serve Enterprises and Deeply Integrate into Them and Conduct Modern Apprenticeship Talent Training}

Higher vocational colleges should fully mine their conditions and advantages in post training, logistics business process reengineering, logistics operation management and other technical services, take the initiative to serve enterprises, and work with enterprises to manage logistics operations in related areas. At the same time, they should actively integrate into enterprises, and address enterprises' management and technical problems in the process of logistics operation and management, as well as problem of human resource development, so as to promote the cooperation between colleges and enterprises to build a training base. Besides, the benefit mechanism and evaluation mechanism of collegeenterprise cooperation should be established to ensure the sustainable development of college-enterprise cooperation training bases and lay a solid practical teaching foundation for the training of modern apprenticeship talents.

\section{B. Carrying out a Top-level Design for Modern Apprenticeship System and Implementing "Modular" Off- campus Training Program}

Colleges should give play to the collaborative effect of offcampus training bases, and carry out a top-level design on the "general module and characteristic module" training project for the training base. The "general module and characteristic module" training project for off-campus training base of higher vocational logistics management major refers to a general module training project which is composed of seven functions of logistics services of "transportation, storage, distribution, circulation processing, handing, packaging and information" based on supply chain management and design on the premise of meeting the training objectives of professional talents. "Characteristic module" training project should be developed based on the personalized needs of different enterprise types, industry characteristics and product attributes of manufacturing enterprises, trade circulation enterprises and logistics enterprises in seven functions. "General module" training project is to ensure the basic specifications of professional training and common requirements for comprehensive development. The course of "characteristic module" is mainly to realize diversified cultivation of different industries, different enterprises, and different products to embody personality. "modular" practical teaching and theoretical teaching, it is necessary to incorporate every modular training project into the professional teaching plan of modern apprenticeship system, organically integrate it into the professional teaching curriculum training, professional on-the-job training, graduation design and comprehensive training based on modern apprenticeship system, establish a professional practice teaching management system based on modern apprenticeship system, and evaluate the effect of practice teaching.

\section{CONCLUSION}

In the process of the construction of off-campus training system, first, colleges should speed up the establishment of school-enterprise cooperation personnel training base, and strive to build a number of off-campus training bases matching the practical teaching system of the modern logistics specialty group. Second, colleges accelerate the promotion of collegeenterprise cooperation projects, improve trials of "modern apprenticeship system", carry out the " $1+\mathrm{X}$ certificate" pilot, deepen the reform of the mode of collaborative education between industry and education, and improve the comprehensive quality of talent training to meet the needs of industrial development. Third, college should improve the talent training model oriented by industry development needs, organically connect with industry needs, job standards and production processes in terms of professional settings, curriculum content, and teaching processes, jointly build a practical teaching platform for the integration of industry and education, upgrade the quality of talent training, and lay the foundation for industrial development.

\section{REFERENCES}

[1] Zheng Jianghua, Li Hui. On the Structure of Real Application Teaching Model of School-Enterprise Cooperation. Tianjin Academic Library (3). 2014. 10. (in Chinese)

[2] Yuan Shijun, Hu Yuanqing. Comparative Analysis on the Training Objectives Of Logistics Management Major in "Secondary Vocational Schools - Higher Vocational Colleges - University". Technology Outlook, 2014 (22). (in Chinese) 